Institute for Research on Poverty

Discussion Paper no. 1029-94

\title{
Child Support Enforcement for Teenage Fathers: Problems and Prospects
}

\author{
Maureen A. Pirog-Good \\ Associate Professor \\ School of Public and Environmental Affairs \\ Indiana University \\ David H. Good \\ Associate Professor \\ School of Public and Environmental Affairs \\ Indiana University
}

February 1994

Resubmitted with requested revisions to the Journal of Policy Analysis and Management on January 29, 1994. Support from the Office of Adolescent Pregnancy Programs, U.S. Department of Health and Human Services, is gratefully acknowledged. Work on this article was conducted in part while Maureen A. Pirog-Good was a visiting scholar at the Institute for Research on Poverty at the University of Wisconsin-Madison and while David H. Good was a visiting scholar at the La Follette Institute of Public Affairs at the University of Wisconsin-Madison. 


\begin{abstract}
The NLSY data indicate that about 7.3 percent of teenage males become fathers and that very few of these fathers live with their children. Father absence and the concurrent increase in femaleheaded households are closely associated with the impoverishment of children. Most absent teen fathers never come into contact with the child support enforcement program, and the extent to which they financially support their children informally is not well understood. While the income of absent teen fathers is low in the teen years, it increases over time, as does the potential for collecting child support. Nevertheless, men who were absent teen fathers earn less in early adulthood than men who deferred parenting until age twenty or later and teen fathers who lived with their children. Early establishment of paternity and greater standardization in the treatment of adolescent fathers by the child support enforcement program are recommended. Further, the substantial and persistent income deficit experienced by adolescent fathers who live apart from their children raises an interesting dilemma. While children may benefit financially and psychosocially from living with two parents, the lower income of men who were absent teenage fathers may make them poor marital prospects. This raises doubts about the recent recommendations of some scholars that we should bring back the shotgun wedding.
\end{abstract}




\section{Child Support Enforcement for Teenage Fathers: Problems and Prospects}

\section{INTRODUCTION}

While we know a great deal about adolescent mothers, relatively little is known about adolescent fathers, their educational and labor market outcomes, their interactions with and impacts on their children. A growing literature on fathers, not specifically teen fathers, suggests that under certain circumstances, fathers promote the cognitive, educational, emotional, and developmental outcomes of their children, particularly boys (for reviews of the literature, see Radin, 1981; Lamb, 1981; or Lamb et al. 1987). In light of these potential benefits, some have suggested that we should bring back the shotgun wedding (Chase-Lansdale and Vinovskis, 1987). Others, however, have argued forcefully that it is irresponsible to encourage the highly unstable marriages of young adults (Furstenberg, 1988). Legislative changes in the mid- and late 1980s have represented a compromise between these two positions by insuring that more and more fathers take responsibility for their children through our nation's Child Support Enforcement (CSE) program. As the rate of births to young men between the ages of fifteen and nineteen is increasing dramatically, with a 12 percent increase between 1988 and 1989 alone (National Center for Health Statistics, 1991), it is important to clarify the extent to which teen fathers can assume financial responsibility for their children.

This article addresses this issue by identifying the ages at which young men become fathers in addition to their ability to pay child support. Using data from the National Longitudinal Survey of Labor Market Experiences-Youth Cohort (NLSY), this article further distinguishes the labor market experiences of adolescent fathers who live continually with their children from those who are the targets of the CSE program: young men who regularly or intermittently live apart from their children. Treatment of teen fathers by the CSE program is described, and the wholesale application of more 
rigorous CSE enforcement for this population is discussed in light of the short- and long-term potential of teen fathers to contribute to their childrens' economic well-being.

\section{THE CSE PROGRAM AND TEENAGE FATHERS}

Nearly half of the children born today will live in a single-parent household before reaching their eighteenth birthday, and most of them will be potentially eligible to receive child support (Bumpass and Sweet, 1989). The CSE program, Title IV-D of the Social Security Act, was enacted in 1975 to establish and enforce the support obligations of these children. States take the primary responsibility for administering the CSE program, although the federal government shares the administrative costs, monitors, evaluates, and provides technical assistance, and, under certain conditions, directly assists in locating absent parents and obtaining support. Amendments to Title IVD in 1984 and the Family Support Act of 1988 have provided states with a wider range of policy instruments to use in establishing paternities and support orders and enforcing those orders. An estimate of the number of teen fathers who come into contact with the CSE program and their movement through this system are described below.

Approximately 203,000 males become fathers each year after their fifteenth birthday and prior to age twenty. ${ }^{1}$ The percentage of these fathers who come into contact with the CSE program is undoubtedly less than the 30 percent rate for all unmarried fathers reported by the U.S. House of Representatives (1991: 720). The paternity adjudication rate of 20 percent for teenage mothers in Wisconsin calculated by Danziger and Nichols-Casebolt (1988) is probably much closer, given that their figure is based solely on teens. ${ }^{2}$ If this rate is applied to teenage fathers, it suggests that approximately 40,600 young men become involved in paternity and child support proceedings each year. 
For teen fathers, movement through the CSE system begins with the establishment of paternity. Paternity can be established via criminal or civil proceedings, and can be contested by the putative father or established voluntarily in either type of proceeding. In contested cases, blood tests can be mandated, which often prolongs the paternity proceedings. One researcher found that when establishing paternity for teenage fathers, procedural delays are pervasive, generally ranging between eighteen months to five years (Wattenberg, 1988). Another study found that 84 percent of the paternity cases of teen fathers are contested and typically take over a year to adjudicate (Pirog-Good, 1988).

The court system does not work well for adolescent fathers. Even if a paternity defendant cannot afford an attorney, their right to court-appointed counsel is far from settled as a national issue (Kohn, 1987). However, if the teenage father has not reached the age of majority (age eighteen in most states), courts may appoint a guardian ad litem, usually a lawyer or one of the defendant's parents, depending on the state in which the paternity case is adjudicated. Unfortunately, guardians $a d$ litem are not routinely available in paternity cases (Wattenberg, 1988; Pirog-Good, 1992).

Additionally, in civil paternity proceedings, a default judgment can be entered. Even if the alleged father does not appear in court, cooperate, contest, or acknowledge paternity, the court can find him to be the father. One survey found a variety of explanations for default judgments, including that the defendant does not understand his rights, cannot afford counsel, and is intimidated by the system, explanations which are likely to be especially true for teenagers (Kohn, 1987).

Some jurisdictions are reluctant to prosecute paternity cases while the absent parent is a minor. Nine states indicate that there are some teen fathers who are so young that the states do not attempt to establish paternity (Pirog-Good, 1992). A ten-state survey found that some paternities involving teen fathers were not adjudicated because the custodial parent either did not need and/or want paternal involvement, the CSE program could not locate the absent parent, the potential for collection and cost 
recovery was low, a guardian ad litem was needed, or there were unresolved issues concerning counsel for indigent defendants (Kohn, 1987). However, the probability of ever establishing a paternity diminishes with time (McLanahan, Monson, and Brown, 1992; Danziger and Nichols-Casebolt, 1988). Thus, deferring paternity adjudications of teen fathers reduces the likelihood of ever legally establishing paternity.

Once paternity is established, the amount of the child support award must be determined. At the support stage, there is no body of state law that suggests that very young fathers should be held to a different standard due to their age (Danziger and Nichols-Casebolt, 1988). In fact, national legislation continues to press states towards greater consistency in the amount of support awarded through state guidelines mandated by the 1984 amendments to Title IV-D. As a consequence of the 1988 Family Support Act, there is now a rebuttable presumption that the amount of child support awarded be the amount specified in a state's guidelines.

Factors considered in determining the amount of the child support award vary from state to state. In general, the obligor's ability to pay and the cost of raising the child figure prominently in this determination. However, even though a teen father may be unemployed and enrolled in school full-time, support may be ordered to establish the principle of the parent's obligation to provide monetary support to his child. ${ }^{3}$ More than half of all states have required some teen fathers under age sixteen to pay child support (Pirog-Good, 1992).

While the use of state guidelines may have reduced within-state variation in the amounts of support awarded, there remains considerable variation across states for obligers in identical economic circumstances. For example, using 1989 state guidelines, an absent father earning $\$ 720$ per month would be required to pay $\$ 27 /$ month in New York but $\$ 325 /$ month in Indiana for two children (PirogGood, 1993a). The extent to which judges and CSE administrators are willing to relax state guidelines 
for teenage fathers, particularly in states where high support awards are the norm, is simply not known.

The limited available evidence suggests that, prior to the Family Support Act, the weekly support obligations of teenage fathers ranged from $\$ 0$ to $\$ 50$. Some jurisdictions did not require support from teenage fathers while others routinely sought token awards of $\$ 5$ to $\$ 15$ per week (Kohn, 1987). One study of 333 teenage fathers found average support awards of $\$ 21.40$ in 1984 (PirogGood, 1988). A second larger study of 1,250 young (but not necessarily teenage) fathers found an average weekly award of $\$ 25.20$ between 1980 and 1985 (Danziger and Nichols-Casebolt, 1988).

After a child support order has been obtained, the CSE program enforces that order. Since 1984, there has been enormous growth in the tools available to CSE program administrators for support collection. These tools now include automatic wage withholding, delinquency notices, regular billings, liens on personal and real property, reporting of arrearage to credit bureaus, seizure and sale of property, garnishment of wages, federal and state tax garnishment, the interception of unemployment benefits, civil or criminal contempt-of-court charges for nonsupport, and incarceration. Unfortunately, little is actually known about the effectiveness of these tools in procuring support from teenagers.

To summarize, the treatment of teenage fathers by the CSE program is not well understood at a national level. While there is greater uniformity in the amount of child support ordered within states, across-state variation is the norm. With regards to the establishment of paternity and support orders and the enforcement of child support for teen fathers, within-state uniformity is the exception. State and local jurisdictions are denied the benefit of a well-articulated national policy on the treatment of teenage fathers. This lack of direction undoubtedly stems in large part from our lack of information concerning the characteristics of the teenage father population, knowledge which we attempt to provide in this article. The data and methods used in this study are described in the next section, which is 
followed by a description of the size of the teenage father population, their ability to pay child support, and the ramifications of different collection strategies.

\section{THE DATA AND METHODS}

In this study, we use the National Longitudinal Survey of Labor Market Experiences-Youth Cohort (NLSY). It is a nationally representative, thirteen-year panel including data on 6,403 males who were fourteen to twenty-one years of age in 1979, the initial survey year. Data up through 1991 are currently available. Annual response rates are high, with 90.5 percent of respondents interviewed in 1991 (Center for Human Resource Research, 1992). Because the NLSY oversampled blacks, Hispanics, and poor whites, the data contain a larger absolute number of teenage fathers than would be present in a purely random survey. Although the number of teen fathers varies across survey years, there are approximately 650 teenage fathers who can be identified in the NLSY. This study utilizes the NLSY weights for each respondent in each survey year. These weights reflect the probability of each person's inclusion in the sample, allowing us to generate national estimates from the data.

The NLSY is conducted with well-trained interviewers and focuses primarily on less sensitive issues such as labor market experiences, rather than on more personal issues such as fertility. Nevertheless, enough data on fertility are available for the purposes of our analysis. The fertility data are not without problems, however. A 1983 study of the NLSY fertility data found discrepancies which could not be resolved for 28 percent of the male respondents who had reported a live birth as of the 1982 survey. The most common inconsistency was the acknowledgment of the birth of a child for the first time in 1982, even though the child had been born prior to the 1981 survey (Mott, 1983). In the present study, the male fertility data were used simply to determine if the respondent had a biological child in his teen years. Hence, a serious problem was not presented by the late reporting of births, which was likely due to new knowledge of births as well as delayed willingness on the part of 
some respondents to acknowledge paternity. Since the youngest respondent turned twenty in 1985, there were at least six years to capture late reports of births to teens.

On the other hand, a 1985 study of the NLSY male fertility data suggests that births to males ages twenty to twenty-four in 1982 may have been underreported by as much as 15 percent, with underreporting more pronounced among black respondents (Mott, 1985). Although some of the young men who became fathers in 1982 waited until after 1982 to report that they had fathered a child, others never reported this fact. Unfortunately, we know of no obvious way in which to correct for births that were never reported. There are two implications of the underreporting problem for this research. First, the sample of young men who acknowledged births is undoubtedly biased in favor of fathers who have taken responsibility for their children. Second, the differences between teen fathers and young men who deferred parenting are likely to be understated since it is likely that some young men who were teen fathers were erroneously included with the young men who deferred parenting. Further, because underreporting was most pronounced among nonwhites, differences between nonwhite teen fathers and other nonwhites will be the most seriously understated.

Several additional methodological points merit elaboration. First, the presence or absence of a teen father was assessed for each child born during the respondent's teen years. A father was considered to be present for a given child when he was reported to be living with the child during each of the four years following the child's birth. If he was not living with the child during any of the four years, he was considered absent. In a few cases, either because the child was born before the beginning of the survey or because the respondent was not administered the survey for a particular year, the respondent was considered to be present as long as he was present for all years for which data were available, and data were available for the fourth year. Further, to be considered present, a father must be present for a four-year period for every child born during his teen years. These criteria resulted in the identification of 236 teen fathers as present, 414 as absent, and 20 as missing. 
Our choice of the four-year period was driven by two objectives. On the one hand, we wanted to be able to include information about the very young fathers in our sample, yet at the same time, we wanted to subject each father to the same hazard. ${ }^{4}$ Were we to choose a shorter period, we would lose several cases where the child was born prior to the beginning of the survey. Were we to choose a longer period, we would lose several cases where the fifth year of data was not yet available for the youngest cohort of teen fathers in the NLSY. In addition, using a longer period would have tilted the sample toward the behavior of $25+$ year olds where divorce and separation are much more likely to occur for both teen and nonteen fathers. We also rejected using information about living arrangements only during the respondent's teen years since this would subject the teens to differential hazards. It would exaggerate the likelihood that the older teen fathers were much more likely to remain with their children than the younger teen fathers, because it would subject nineteen-year-old fathers to the hazard of divorce/separation for less than one year, while it would subject the youngest teen father in our sample to this hazard for over eight years.

The definition of income also requires some elaboration. Our definition includes earnings from wages, salary, commissions, and tips from all jobs where employment in the formal and informal sectors is not distinguished. Also included in our definition of income is military earnings, profits from businesses owned by the respondent, and unearned income (dividends, interest, etc.). We used this definition because it provides the most comprehensive representation of the resources available for fathers to share with their children. One possible alternative would exclude business profits and unearned income from income, as these sources of income would be more difficult for a child support office to attach. Nevertheless, we felt that it was important to identify all of the financial resources of young men, regardless of the difficulty of securing this income as child support. Further, we used the income earned over a calendar year to describe the annual income of each respondent at his age on June 30 of the calendar year, and all incomes were measured in real terms using 1982-1984 as the 
base period. Consequently, the 1983 poverty threshold was used in determining if the incomes of adolescent fathers were below the poverty line.

Since our objective is to identify the short- and long-term consequences of teenage paternity, it was essential to summarize the income data for individuals at different ages. One standard way to deal with this situation is to aggregate individuals of similar ages together, say young men ages sixteen to seventeen, and use sample means to summarize the age-income data. However, this approach "muddies" the age-income profiles. For example, young men who were nearly seventeen and who had just turned seventeen would be placed in different age categories even though their earning powers are presumably quite similar. This is particularly problematic because earning power is changing rapidly over the period of interest. While we wanted to summarize the income data, we wanted to impose as few restrictions on the shape of the age-income profiles as possible. We chose to do this by modeling the age-income profiles using regression analysis with a tenth-order Taylor series expansion about the sample mean ages. While not commonly used in the social sciences, this approach is common in the engineering response function literature (Box and Draper, 1987). Sensitivity analysis indicated that very little structure was imposed by the tenth-order series on the age-income profiles we generated. Higher order series produced virtually identical results. Further, this approach substantially smoothed the age-income profile, but made it virtually impossible to extrapolate beyond the range of the sample. In fact, only three months after the end of our sample (age thirty-two), confidence intervals for the expected income increased dramatically to over $\$ 50,000$ wide. Although the tenth-order polynomial introduced substantial collinearity among regressors, the predicted values of the dependent variable, income, were quite stable.

TEENAGE FATHERS AND THEIR ABILITY TO PAY CHILD SUPPORT

\section{All Teen Fathers and Absent Teen Fathers}


Examination of the weighted NLSY data reveals that at least 7.3 percent of all males become fathers prior to the age of twenty in the United States. Further, 57.0 percent of these young men do not live with their children. Figure 1a indicates the percentage of all young men who become teen fathers and absent teen fathers between the ages of fourteen and twenty. Ninety-five percent confidence intervals for both series are represented by the dashed lines. Panels $b$ and $\mathrm{c}$ of figure 1 provide the same information for whites and nonwhites, respectively. Figure 1a illustrates that most males who become teen fathers do so between the ages of seventeen and nineteen.

By the age of seventeen, only 0.79 percent of the male population has become a teen father and 0.52 percent of the male population can be classified as absent teen fathers. Even when the analysis is restricted to males who eventually become teen fathers, only 10.8 percent of all teen fathers and 12.4 percent of absent teen fathers achieve this status prior to age seventeen. However, as seen in panels $\mathrm{b}$ and $\mathrm{c}$ of figure 1 , these patterns are substantially different for whites and nonwhites. ${ }^{5}$ Only 5.8 percent of white males become teen fathers, in contrast to 15.1 percent of nonwhites. Further, very early parenting, having a child prior to age seventeen, is more than eight times more common among minorities than whites. Fully 2.9 percent of nonwhite males become parents prior to age seventeen. Moreover, this race differential in early parenting is undoubtedly understated as births to black males are the most seriously underreported in the NLSY.

The fact that teen fatherhood is much more common among older teens, both whites and minorities, is somewhat heartening, given that the youngest fathers are the least likely to possess the maturity and financial ability to contribute to the support of their children. Further, due to the length of time required to adjudicate paternity cases, the CSE program probably has to deal with very few young men who are legally prohibited from holding most jobs because of their age. However, some 
figure 1 here 
very young putative fathers will come into contact with the CSE program, and, consequently, it is important for CSE jurisdictions to establish and implement guidelines to safeguard the rights of very young teenage fathers. This will become more important given the increasing trends toward adolescent paternity and the use of expedited paternity processes mandated by the Family Support Act.

\section{All Teen Fathers and Males Who Delay Parenting Until Age 20 or Later}

To determine the extent to which young fathers can support their children, the age-income profile of teenage fathers was compared to the age-income profile of young men who never became teen fathers. Panel a of figure 2 provides this information for all males while comparable information for whites and nonwhites is given in panels b and c. Dashed lines provide 95 percent confidence intervals for the average in each series.

First, figure 2a shows that the average income of all teenage males prior to age sixteen is quite minimal, and, consequently, rigorous enforcement of child support orders can be questioned on both practical and ethical grounds. Second, teenage fathers enter the labor force earlier than their nonfather peers. Between the ages of seventeen and twenty-two, teenage fathers have higher incomes than their nonfather peers. This may be a result of an attempt on the part of the teen fathers to support their children. Alternatively, the characteristics or environments of some young men may incline them to enter the labor force as well as have children. Third, teenage fathers consistently have lower average incomes after age twenty-three than the young men who were never teen fathers. These differences in income are quite large. On average, by age thirty, teen fathers earn only $\$ 13,783$, roughly two-thirds of the earnings of males who delay parenting until age twenty or later. By age thirty-two, this difference increases to nearly 40 percent or $\$ 8,475$ per year.

The early labor force entrance and lower income after age twenty-three is consistent with the fact that teen fathers complete fewer years of education than do their nonfather peers. The NLSY 
Figure 2 here 
data used for this study show that by age twenty-three, only 64.7 percent of teen fathers have a high school diploma or GED compared to 84.9 percent of other young men $(\mathrm{p}<.0001)$. On average, by age twenty-three, teen fathers have completed 12.35 years of formal schooling, 2.14 fewer years than men who deferred parenting until after age twenty $(\mathrm{p}<.0001)$. This larger human capital investment of nonfathers eventually translates into higher incomes for this group.

Panels $\mathrm{b}$ and $\mathrm{c}$ of figure 2 show somewhat different patterns for whites and nonwhites. The pattern for whites parallels that of all males but is slightly more pronounced. White teen fathers initially have larger incomes than other white males until age twenty-three. By age thirty-two, white teen fathers earn on average only $\$ 17,100$, compared to $\$ 25,672$ for other white males. For minorities, however, the age-income profiles of teen fathers and other males are much more similar to one another. The averages are statistically indistinguishable until age twenty-six when the incomes of nonwhite teen fathers fall short of the incomes of other nonwhite men. Still, by age thirty-two, the average income of nonwhite teen fathers is $\$ 4,692$ less than the $\$ 16,509$ income of other nonwhite males. The fact that the incomes of minority teen fathers and other minority males are similar until age twenty-six most likely results from fewer work opportunities being available for this population. Moreover, readers should recall that income differentials between teen fathers and nonteen fathers (all, whites and nonwhites) are likely to be larger than reported here because of the underreporting of teenage paternity, particularly among nonwhites.

Thus, figure 2 clearly indicates that the price of teen fatherhood (in terms of foregone income) is lower for nonwhite males than whites. At age thirty-two, white teen fathers earn $\$ 8,572$ less or 66.6 percent of the income of other white males, whereas nonwhite teen fathers earn $\$ 4,692$ or 71.6 percent less than nonwhite males who delay parenting until age twenty or later. An appropriate policy response to this price differential is unclear. One way to raise the price of teen fatherhood might involve initially limiting the labor market opportunities of teen fathers. However, this approach is 
objectionable for two reasons. First, teen fathers should be encouraged to regularly provide some economic support for their children, and limiting job opportunities would conflict with this objective. Second, raising the price of teen fatherhood for nonwhites by limiting their job opportunities would rightfully meet with cries of injustice as discrimination in the labor market is undoubtedly one of the reasons why the price of teen fatherhood is lower for nonwhite males. It would appear that if we want to raise the price of adolescent paternity for teen fathers, we must search for nonpecuniary approaches, perhaps requiring parenting classes and more shared responsibilities for child care.

\section{Teen Fathers Who Live with and Apart from Their Children}

Unfortunately, from the perspective of collecting child support, teenage fathers are not a homogeneous lot. Fathers who live apart from their children have different labor market experiences than do fathers who live with their children. This is demonstrated by comparing the age-income profile of absent teen fathers with that of teen fathers who live with their children (figure 3a). Panels

$3 \mathrm{~b}$ and $3 \mathrm{c}$ provide the same comparisons for whites and nonwhites, respectively. Again, 95 percent confidence intervals for average incomes are represented in both series by dashed lines.

Figure 3a shows that the incomes of young fathers who live with or apart from their children are statistically indistinguishable until they reach 17.4 years of age, after which males living with their children have higher average incomes. By age twenty-five, men who live apart from their children have incomes of only $\$ 10,288$, or approximately 70 percent of the incomes of present fathers. By age thirty, this difference increases to $\$ 4,477$, leaving absent fathers only 73 percent of the income of men living with their children.

Because figures $3 \mathrm{~b}$ and $3 \mathrm{c}$ deal only with white and nonwhite teen fathers, the number of observations on which the age-income profiles are based is necessarily smaller than in figure $3 \mathrm{a}$ or earlier figures. The smaller sample sizes, particularly for absent white fathers and present nonwhite 
figure 3 here 
fathers, result in larger confidence intervals surrounding the age-income profiles. Nevertheless, the patterns for whites and nonwhites are remarkably similar. Men who live with their children generally have higher incomes than men living apart from their children. However, these income differentials are more pronounced among nonwhites. For example, for nonwhite males between the ages of twenty and thirty, the income of absent teen fathers is as little as 58.6 percent and never exceeds 75.7 percent of the income of teen fathers who live with their children. In contrast, over this same time interval, the income of absent white fathers ranges between 71.8 percent and 93.81 percent of the income of white fathers living with their children.

These findings are consistent with the hypothesis of Wilson (1987) that some men are absent fathers because they are financially incapable of supporting a family. If this thesis is correct, it would explain why a much higher percentage of minority males live apart from their children. An alternative explanation is that there are some characteristics of absent teen fathers which make them inclined to remain apart from their children and underemployed. In either case, the implications of these findings for the CSE program are discouraging. If young men who are the least capable of providing financially for their children are more likely to be absent fathers, this self-selectivity will necessarily make it more difficult for the CSE program to collect child support.

That the income of absent fathers typically falls short of the income of men who live with their children does not necessarily imply that they are not attempting to earn additional income to support their offspring. To examine their motivation, differences in the incomes of absent and present teenage fathers before and after the birth of their children were compared. In figure 4, zero on the horizontal axis refers to the point of birth, with positive and negative values referring to the number of years after and prior to the birth of the first child, respectively.

Several interesting conclusions can be drawn from figure 4a. First, the increase in income at the point of the birth is statistically significant for men who live apart from their children (though at 
Figure 4 here 
only the 10 percent level). On average, the annual income of absent fathers one month after the birth is $\$ 1,788$ or 45.6 percent greater than it had been one month prior to the birth. This suggests that even absent fathers attempt and are somewhat successful at earning additional income to provide for their children. In comparison, the increase in income at the point of birth is not statistically significant for men who live with their children. This finding probably reflects better opportunities or planning on the part of these young men, whose incomes exceed those of absent fathers as early as twenty-two months prior to the first birth. Second, men who live with their children have higher incomes before the birth and during the ten-year period after the first birth. Three months after the birth and continuing thereafter, the income of absent fathers is roughly two-thirds the income of men who live with their children. These differences are not inconsequential. Following the birth of the child, men who live with their children have incomes sufficient to support a family of three at 111 percent of the 1983 poverty threshold for a family of three. At the same time, the income of absent fathers is only 70.9 percent of the poverty threshold for a family of three. It is not until nearly four years after the birth that the income of absent fathers is adequate to support a family of three at the poverty threshold.

Panels $\mathrm{b}$ and $\mathrm{c}$ of figure 4 provide the same information for whites and nonwhites, respectively. For whites, the profiles generally follow the same pattern described above, although at higher levels of income. For the ten-year period following birth, absent fathers generally earn 75 to 80 percent of the income of present teen fathers. Still, the white absent teen father's average income of $\$ 8,715$ one year after birth and $\$ 10,050$ five years after the child's birth is adequate to support a family of three at the poverty threshold level of $\$ 8,015$, reflecting the higher incomes of white teen fathers in general. In stark contrast in panel 4c, nonwhite absent fathers earn an average of only $\$ 4,423$ (55.3 percent of present teen fathers) one year after the birth of the child, partially reflecting their younger age. It isn't until approximately five years after the first child's birth that nonwhite absent fathers earn enough to support a family of three at the poverty level. These differences 
between white and nonwhite absent fathers may explain why a much smaller percentage of white teen fathers live apart from their children. The NLSY data indicate that at age nineteen, only 46.7 percent of white teen fathers are absent parents, in contrast to 81.7 percent of minority fathers.

Overall, these results suggest that while the typical absent teen father earns income and can provide some support for his children, the magnitude of the support award deserves serious consideration given the heterogeneity of individual income levels. A total of 52.3 percent of absent teenage fathers lived in poor households at the time of the birth of their first child. The strict enforcement of significant support orders will push the households of even more teenage fathers below the poverty threshold. Under the Wisconsin model, the amount of child support awarded is equivalent to 17 percent of gross income for one child, and 25, 29, 31, and 34 percent, respectively, for 2, 3, 4, or 5 or more children. Strictly applying even this modest guideline for support awards would push an additional 2.3 percent of the households of teen fathers into poverty. Alternatively, a flat support award of $\$ 25$ per week would increase the percentage of teen-father households in poverty by 5.1 percent to 57.5 percent. Thus, because of the low economic resources of the households of many absent teenage fathers, rigorous CSE enforcement may result in merely shifting poverty, along with its societal burdens, from one household to another. Providing disincentives to prospective teen fathers and fairness to the children of teenage males must be weighed against the likely increases in poverty in teen-father households that will result from collecting child support from adolescent males.

Practically speaking, the income available for child support is very limited for very young fathers. At age sixteen, the annual income of absent fathers is $\$ 896$. Even if every dollar of income was used for child support, this would total only $\$ 17.23$ per week. Further, if child support is viewed as an income tax by absent parents, then given the low earnings of very young absent fathers, even moderate child support awards may seriously discourage work on the part of this population. Hence, if we wish to encourage very young fathers to take financial responsibility for their children by 
establishing token awards, the size of these awards must be quite low. However, although the income of absent teen fathers remains typically lower than that of other men, it increases during the late teens and early twenties. By age twenty, the annual income of absent fathers is $\$ 6,488$ and by age twentythree it is $\$ 8,285$. Hence, establishment of paternity and frequent modifications of support awards to reflect the increases in earnings of young fathers should be encouraged.

\section{DISCUSSION}

Despite the underreporting of births to adolescent males in the NLSY, our results confirm that teenage fatherhood, and in particular absent teenage fatherhood, is a serious social problem. The majority of programs which deal with teen parenting, such as supplemental education programs, are directed toward mothers. We suggest that teen fathers merit special attention. Further, absent adolescent fatherhood poses a serious dilemma. On the one hand we want these individuals to be responsible for their actions. On the other hand, they are clearly unable to provide the same kind of financial support which we would expect of adults. This has a variety of implications for the operation of the CSE program.

The 1988 Family Support Act set goals for the number of paternities established by states with financial penalties for states failing to meet those goals. It makes no distinctions in cases dealing with adolescent fathers. The increased emphasis on paternity establishment should be supported and encouraged even for minor putative fathers, given that the probability of ever establishing paternity

declines over time. By failing to establish paternity, children cannot obtain child support orders, are denied Social Security and Worker's Compensation coverage in the event of injury or death of the absent parent, and may be denied access to potentially important medical records (Children's Defense Fund, 1987). 
Since the benefits of establishing paternity are numerous, it is shocking that paternity is established for such a small percentage of absent teenage fathers. The vast majority of absent teenage fathers fail to come into contact with the CSE program (U.S. House of Representatives, 1991; Danziger and Nichols-Casebolt, 1988). Whether or not these fathers make private arrangements with the mothers of their children to provide support is not well documented. It is likely that paternity is never established for many children simply because their custodial parents are unaware of the benefits of paternity establishment and services provided by the CSE program. Outreach services to middle and high schools should clarify the services available for teen parents. More research is needed to ascertain the well-being of the children of the vast majority of teenage fathers who fall outside the purview of the CSE program.

When a paternity case is adjudicated for an absent father who is a teenager, local jurisdictions must make the putative father aware of the implications of paternity establishment, his right to contest the paternity, and his right, if it exists, to a guardian ad litem or court-appointed counsel. When the defendant has a right to a guardian ad litem or court-appointed legal counsel, that right must be safeguarded. Further, a national resolution to the debate concerning the right to court-appointed legal representation for indigent defendants is clearly warranted.

Our study suggests that judges should have considerable discretion when setting the amount of child support awards. While greater uniformity in the amount of support awards is generally desirable, departures from state guidelines should not be discouraged for teenage fathers. Such departures will avoid setting unrealistically high support awards which may contribute to the early departure of our youth from schools and the shifting of poverty from household to household. This is particularly important given that the majority of absent teenage fathers already live in poor households. Further, the impacts of token child support awards for teenage fathers on their support compliance during adulthood are simply not known. Research on this topic is needed. 
Attention should also be focused on the few CSE programs across the country that have adopted innovative approaches in their dealings with teen fathers (for a description of several of these programs, see Association of Maternal and Child Health Programs, 1991). For example, the Teen Alternative Parenting Program (TAPP) in Marion County, Indiana, allows young fathers to use in-kind credits for the payment of child support. Each father signs one or more ninety-day contracts in which a certain amount of child support will be considered "paid" if the youth completes a week of school without any unexcused absences, attends parenting classes, babysits his child, and/or attends GED, vocational education, or training classes. The emphasis on child care and developing good parenting skills in TAPP explicitly acknowledges that fathers, even young absent fathers, can contribute in many ways to the development of their children (Pirog-Good, 1993b). In a program offered through the Department of Social Services on behalf of the New York City CSE program, teen fathers volunteer to receive education and training and counseling on parenting, budgeting, and sex education. In exchange for these services, the fathers provide items such as diapers or milk toward the support of their children. Yet another possibility is to suspend child support payments for in-school fathers until the summer and Christmas recesses when they might be expected to work to support their child, labor market conditions permitting. The success and replicability of these approaches should become an objective of the CSE program at a national level.

If an alleged absent father has not been informed of his right to contest paternity or informed of his right, if it exists, to court-appointed counsel or a guardian ad litem, or if the amount of child support ordered is unrealistically high, then vigorous enforcement of child support orders raises very serious ethical problems. However, provided that the rights of teenage fathers are protected when establishing paternity and that reasonable support award amounts are mandated, child support orders should be enforced. If a teenage father has the ability to pay child support and refuses, the enforcement techniques used for adults should be applied to juveniles. However, the CSE program 
would clearly benefit from research designed to determine the short- and long-run effectiveness of the myriad of policy instruments available to elicit child support. Further, such research should clearly distinguish between the adult and juvenile populations of obligers as the effectiveness of these instruments is likely to be very different for these populations.

Finally, the lower income of absent fathers implies that there are fewer resources for the CSE program to tap and that the potential financial benefits of the marriage of mothers and absent fathers discussed by Chase-Lansdale and Vinovskis (1987) may be overstated. Also, the lower income of absent fathers lends some support to the notion that some men do not form families because they cannot afford to support themselves and their children. However, our research does not address whether the low income of absent fathers is a consequence of poor economic opportunities and whether low income is why some men remain apart from their children. Nevertheless, these hypotheses are clearly consistent with our data. Alternatively, it is also possible that the characteristics of absent fathers incline them to perform poorly in the labor market and remain absent from their children. This distinction is critical and should be researched further, particularly given the recent emphasis on work programs for absent parents whose children are supported by AFDC. 


\section{Notes}

${ }^{1}$ This figure was estimated using the birth rate of 22.4 births per 1,000 males $15-19$ years of age provided in National Center for Health Statistics (1991). This rate was applied to the total number of 15- to 19-year-old males in the United States (resident population) from the U.S. Bureau of the Census (1990).

${ }^{2}$ Similar figures are given by Adams et al. (1989). Unfortunately, all of these figures are based on births to teenage mothers, not fathers. Data on the percentage of births to teenage men resulting in a paternity adjudication are not available at the state, regional, or federal level. Thus, the 40,600 figure should be viewed as a best estimate.

${ }^{3}$ For example, the Colorado child support guidelines (revised August 1987) indicate that a specific amount of child support should always be ordered, no matter how minimal, so as to establish the absent parent's obligation to provide monetary support.

${ }^{4}$ Our use of the term hazard is consistent with the survival analysis literature to describe the probability that a failure will occur (in our case, an absent teen father) at some time. Practicality dictates that we measure this phenomena over an interval rather than at an instant in time. Obviously, for an individual at a given level of risk of failure, the longer the measurement period, the higher this probability. Consequently, we must use the same-length time interval for all individuals. Were we to do otherwise, two individuals, at the same level of risk, would, on average, result in different probabilities of failure over their respective intervals. (We call this the differential hazards problem.) It is essential that we are sensitive to this potential problem and use the same-length time period for all individuals.

${ }^{5}$ Nonwhites include blacks and individuals of other races. There were insufficient observations on individuals of other races to perform separate analyses. For our analyses, there were 4,323 white males, 1,589 black males, and 361 males of other races with complete information. Once these data 
are weighted using the NLSY weights to generate nationally representative statistics, white, black, and other males constitute $82.7,13.8$, and 2.9 percent of the sample. 


\section{References}

Adams, Charles, David Landsbergen, and Larry Cobler. 1989. "Welfare Reform and Paternity Establishment: A Social Experiment." Presented at the 1989 meetings of the Association for Public Policy Analysis and Management.

Association of Maternal and Child Health Programs. 1991. Adolescent Fathers: Directory of Services. Washington, D.C.: National Center for Education in Maternal and Child Health.

Bumpass, Larry L. and James A. Sweet. 1989. "Children's Experience in Single-Parent Families: Implications of Cohabitation and Marital Transition." Family Planning Perspectives 21(6): $256-259$.

Box, George and N. R. Draper. 1987. Empirical Model Building and Response Surfaces. New York: Wiley.

Center for Human Resource Research, the Ohio State University. 1992. NLS Update: The National Longitudinal Surveys of Labor Market Experience 73 (Fall): 1-2.

Chase-Lansdale, P. Lindsay and Maris A. Vinovskis. 1987. "Should We Discourage Teenage Marriage?" The Public Interest 87 (Spring): 23-37.

Children's Defense Fund. 1987. Child Support and Teen Parents. Adolescent Pregnancy Prevention Clearinghouse.

Danziger, Sandra K. and Ann Nichols-Casebolt. 1988. "Teen Parents and Child Support: Eligibility, Participation and Payment." Journal of Social Service Research 11(2-3): 1-20.

Furstenberg, Frank F. Jr. 1988. "Bringing Back the Shotgun Wedding." The Public Interest 90 (Winter): 121-127.

Kohn, Margaret A. 1987. Child Support Enforcement and Young Unwed Fathers. Washington, D.C.: National Legal Resource Center for Child Advocacy and Protection, American Bar Association. 
Lamb, Michael E. 1981. "Fathers and Child Development: An Integrative Overview." Pp. 1-70 in Michael E. Lamb (ed.), The Role of the Father in Child Development. New York: John Wiley.

Lamb, Michael E., Eric L. Charnov, and James A. Levine. 1987. "A Biosocial Perspective on Paternal Behavior and Involvement." Pp. 111-142 in Jane B. Lancaster, Jeanne Altman, Alice S. Rossi, and Lonnie R. Sherrod (eds.), Parenting across the Lifespan: Biosocial Dimensions. New York: Aldine de Gruyter.

McLanahan, Sara, Renee Monson, and Pat Brown. 1992. "Paternity Establishment for AFDC Mothers: Three Wisconsin Counties." Pp. 105-136 in Paternity Establishment: A Public Policy Conference Volume II: Studies of the Circumstances of Mothers and Fathers. Institute for Research on Poverty Special Report 56B, University of Wisconsin-Madison.

Mott, Frank L. 1983. "Fertility-Related Data in the 1982 National Longitudinal Surveys of Work Experience of Youth: An Evaluation of Data Quality and Some Preliminary Analytical Results." The Ohio State University, Center for Human Resource Research.

Mott, Frank L. 1985. "Evaluation of Fertility Data and Preliminary Analytical Results from the 1983 (5th Round) Survey of the National Longitudinal Surveys of Work Experience of Youth." The Ohio State University, Center for Human Resource Research.

National Center for Health Statistics. 1991. Advance Report of Final Natality Statistics, 1989.

Monthly vital statistics report; 40(8), suppl. Hyattsville, Maryland: Public Health Service.

Pirog-Good, Maureen A. 1988. "Teenage Paternity, Child Support, and Crime." Social Science Quarterly 69(3): 527-546.

Pirog-Good, Maureen A. 1992. "Teen Fathers and the Child Support Enforcement System." Pp. 157-190 in Paternity Establishment: A Public Policy Conference Volume II: Studies of the 
Circumstances of Mothers and Fathers. Institute for Research on Poverty Special Report 56B, University of Wisconsin-Madison.

Pirog-Good, Maureen A. 1993a. "Child Support Guidelines and the Economic Well-Being of Our Nation's Children." Family Relations 24(4): 453-462.

Pirog-Good, Maureen A. 1993b. "In-Kind Contributions as Child Support: The Teen Alternative Parenting Program." Pp. 251-266 in Theadora Ooms and Robert Lerman (eds.), Young Unwed Fathers: Changing Roles and Emerging Policies. Philadelphia: Temple University Press.

Radin, Norma. 1981. "The Role of the Father in Cognitive, Academic, and Intellectual

Development." Pp. 379-428 in Michael E. Lamb (ed.), The Role of the Father in Child Development. New York: John Wiley.

U.S. Bureau of the Census. 1990. Current Population Reports, Series P-25, No. 1057, U.S.

Population Estimates, by Age, Sex, Race, and Hispanic Origin: 1989. Washington, D.C.:

U.S. Government Printing Office.

U.S. House of Representatives, Committee on Ways and Means. 1991. Background Material and Data on Programs within the Jurisdiction of the Committee on Ways and Means. Washington, D.C.: U.S. Government Printing Office.

Wattenberg, Esther. 1988. "Young, Unmarried Parents and Paternity Decisions: What Is Known and Not Known." Paper prepared for the Child Support Research Conference, Department of Health and Human Services, Washington, D.C.

Wilson, William J. 1987. The Truly Disadvantaged. Chicago: The University of Chicago. 